\title{
Me and You, We Could be Something for Real: Creating Authenticity since the First Hipster Generation
}

\author{
Rodrigo Almeida Sousa
}

\begin{abstract}
We are living in the Age of You. For it is You who makes the world go round, as you continuously feed our global digital society flow with your opinions, comments, likes, videos, products and services. However, this 'You' is founded on the Network Paradigm - the communicational and linguistic model that replaced the old idealistic Subject - which is rooted in its own forms of subjectivity - Organizations and Individuals both dependent on the Ideology of Me. So the question arises: who is this Me? For organizations, this question does not represent a real problem. But as for individuals, it implies a major existential concern - the authenticity dilemma - which we have been solving through creativity, lifestyle and consumerism, although perhaps we only started to actually realizing it in the beginnings of the 21 st century.
\end{abstract}

Index Terms - Subjectivity, individualism, organizations, authenticity, hipster.

\section{INTRODUCTION}

Ten years ago, Time Magazine openly announced a new era by electing You as the 2006 Person of The Year. Since the late $90 \mathrm{~s}$, individuals were becoming more autonomous then ever before, and the 21 st century not only confirmed individualistic autonomy but also highly exponentiated it. Digital Society was finally established as a pragmatic and effective global reality, particularly in the western world internet actually working in real-time (including audiovisual content downloading), portable HD interactive devices (laptops, tablets, smartphones), user-friendly software and increasingly personalized applications - all resulting in what we might call a 180 transformation of the individualistic Me (worker/consumer) into a You (producer).

But who is this Me living in the Age of You? Talent shows and viral videos illustrate our fascinating obsession with this self-promoting and autopoietic ordinary individual of the 21 st century. By using digital resources the individual does not have to resign himself to what society tells him to be. He can create his own authentic image. Nevertheless, is it not precisely that - creating authenticity - what we have been doing all along, at least since the 1950s? How and when did this social process begin? And why? What philosophical and communicational paradigms allowed it to finally emerge in our contemporary societies?

\section{Methodology}

In order to answer these questions we have adopted an

Manuscript received July 16, 2016; revised August 10, 2015.

Rodrigo Almeida Sousa is with CIC.DIGITAL Research Center University of Porto, Portugal (e-mail: osoja@yahoo.com). hermeneutical approach both in its critical and comparative domains, as this article focuses on two main aspects: Causes and Paradigms; Authenticity and Generations.

Causes and Paradigms: first of all, our objective is to determine the intellectual, cultural and social contexts and evolutions which favored contemporary society to emerge, with its own forms of subjectivity: organizations and individuals. Here, we combine hermeneutics with other approaches such as the phenomenological and communicational (School of Toronto, media supports and shifts as paradigmatic turning points)

Authenticity and Generations: our following, and final objective is to illustrate how each generation since the 1950s was creating authenticity, as we critically and comparatively analyze historical events and cultural products (art, literature, movies, tv shows, viral videos), privileging internet resources as empirical/emblematic data.

\section{LETTERS FROM OUR PAST SELF}

Just a couple of decades have passed since the end of the Electronic Age, and the subsequent beginning of Digital Society, and it is already difficult for us to imagine a world without the internet. So how could we possibly understand, or actually perceive, what kind of world we were living in before television or even radio were in use?

The question is evidently rhetoric. Nevertheless, we can still try, or at least make an effort to describe the distant Gutenberg Galaxy basing our assumptions on books. Particularly, the philosophical ones, published between 1600 and 1850 , whose leading character was simultaneously the main category of post Cartesian modernity - the Cogito, or literally "I think" - which of course does not concern the individual self as much as its universal reference.

From Descartes, Spinoza, Leibniz, Berkeley to Kant, Fichte, Schelling and Hegel, almost all modern authors have based their philosophical systems on the conscience, or what we call the idealistic Subject. In other words, the universal principal of subjectivity, as a living, immanent, affective, logical and intellectual place where everything finds its meaning. For that is precisely the experience we get from reading/writing a book; just Me and my Book, living in the same two-dimensional reciprocity between myself and my narratives. Everything outside must remain a mystery, or in Kantian terms, a noumenon, an unknown something (Kant, 2001, p.297; B312) [1]. Therefore, the Cogito was consigned to its own Gutenberg Galaxy, although not necessarily as a solipcistic individual but as a general category, living among his thoughts and feelings, which could only be shared by the objective/readable structure of the written word, and its printed objects - essays, novels, letters, journals. Limited to his visual perspective, and 
deprived from tridimensionality, the idealistic Subject would behave like a blind man when confronted with external nature. He would be deceived by it, just as Gloucester was mislead by his biological son, the well intentioned though naive Edgar, into believing the illusion that they were at the edge of a steep cliff. (King Lear, IV.6; McLuhan, 2002, p.16) [2].

It is curious how this distant galaxy is so intrinsically far from our own. We keep studying this idealistic Subject in our academic departments of philosophy or humanities. But the problem is, we are no longer able to perceive it as such, as we are emerged in a new reality - our contemporary, tridimensional reconfigured universe, provided by the electronic and digital network we live in. Of course we can understand what Descartes, Berkeley, Kant or Hegel said, as long as we read them in French, English, German, or in a fine Spanish translation. But their media context will always remain the lost enigmatic key for us to actually apprehend their message. In other words, reading their conceptions, intuitions, feelings, thoughts and concerns will inevitably sound to us as we are reading letters from our past self. But does this mean that we abruptly diverged from their idealistic Subject? What really happened to subjectivity since the advent of the electronic communication network of the $20^{\text {th }}$ century?

\section{The Network PARADIGM: SETTING PIECES}

Since the industrial revolution, philosophical works started to focus more on society dynamics and its historical developments. Marx and his materialistic dialectics, Comte and the positivistic approach to social and cultural "facts", Dilthey, Schleiermacher and the beginnings of hermeneutics, are some of the most relevant examples of this theoretical shift. At the same time, other authors, such as Nietzsche and Kierkegaard, also reacting against the tradition of the idealistic Subject, preferred instead to theorize on vitalist and/or pre-existentialist alternatives, more focused on what we generally started referring to, since approximately the 1940 s, as the existential category of the individual self. Moreover, the inner structures of the Self were also the major concern of Freud's psychoanalysis, one of the most influential contributions for the intellectual development of the twentieth century.

But should we consider these intellectual/theoretical works to be the main cause of all our recent history and cultural panorama? Are they the only reason why our society has changed so much in the past 150 years? Of course not, there are so many others - scientific and technological innovations, new energetic resources, economic and political advancements as well as conflicts and wars, all depending on our point of view. Hence, in this respect we may also consider the communicational perspective, for it provides us not only with conceptual knowledge but also with social perception itself. That is, by interpreting media paradigms and shifts across different historical periods, we become aware of how our sensorial worldview affects us - our cognitive and volitive selfstructures - without even noticing. For instance, our perspective of time. According to Harold Innis, spacedbiased mediums - newspapers, radio, television - as opposed to time-biased ones - clay, parchment - have always been correlated to very distinct societies, cultural contexts and historical events.

The tension between western capitalist values individualism, private property, free market, freedom of press, democracy - and its marxist/socialist antagonistic reaction, has been widely spread since the industrial revolution precisely by means of increasingly spaced-biased media. Newspapers enabled politicians, governments, as well as other institutions and lobbies to stimulate the masses, disseminating ideological struggles and bringing diplomatic contentions to the realms of public opinion. Thus, although promoting our most consensual and emblematic contemporary values, the press was also the sine qua non condition to all major conflicts of the first quarter of the twentieth century, such as the Bolshevik revolution and the First World War (Innis, 1995, p.80-81) [3]. But of course the actual sequence of contemporary media innovation began with radio broadcasting, which enabled political leaders to communicate directly with the masses. The monopoly of the eye, grounded on written word, started to give in when confronted with the new appeal to the ear. Illiteracy was no longer an obstacle for the most ruthless propaganda:

"The rise of Hitler to power was facilitated by the use of the loud speaker and the radio. By spoken language he could appeal to minority groups and to minority nations. Germans in Czechoslovakia could be reached by radio as could Germans in Austria. Political boundaries related to the demands of the printing industry disappeared with the new instrument of communication" (Ibid., p. 81)

A new sensorial paradigm was taking place. And in that same period, philosophers were also searching for alternatives to the idealistic Subject and his obsolete literary galaxy. Heidegger translates the greek word Logos for Speech (discourse), as the primordial human action which enables something "to be seen (phainesthai), namely, what the discourse is about; and it does so either for the one who is doing the talking (the medium) or for persons who are talking with one another" (Heidegger, 2001, p.56) [4]. Likewise, Wittgenstein was also formulating his linguistic turn, by distinguishing facts - as given in the logic, immanent, interconnected totality called the world of facts from mere things (1922, p.25) [5]; a theoretical perspective which he revised and definitely consolidated in his Philosophical Investigations, where he introduced his most innovative and sophisticated notions of use, meaning and language-games (1953) [6].

In other words, having finally established this unprecedented network of language/speech as the new basic platform of intellectual activities, at the time when television was becoming the primary medium for influencing public opinion (1950's), both analytical and continental philosophers were merely reflecting the same electronic environment they were already immersed in (McLuhan, 2002, p.248).

\section{The IDEOlogy OF ME AND THE Authenticity DILEMMA}

After the Second World War, the network paradigm was 
already the foundation of postmodern society, culture and philosophical thinking. The two-dimensional perspective of the idealistic Subject had been replaced by the tridimensional organicism of audiovisual media, and its own forms of subjectivity: Organizations and Individuals. For although these categories had always been present across modern history, they became prominent, as they have clearly proven to be the most adaptable, or rather, proficient at playing the leading roles in the electronic age. After all, they fit its ideology as hand in glove.

Since the last centuries, capitalist values were increasingly wining their place in western societies, confronting the power of the states in favor of decentralized civil rights. On one hand, private property, free market and freedom of press allowed non-statal agents - associations, foundations, companies - to emerge as an alternative to public institutions. On the other, democracy and freedom of speech would also empower individuals. Furthermore, individualistic rights to profit and to pursuit happiness favored both categories.

Thus, when finally the old, centralistic, despotic, idealistic Subject, and its literal written word, eventually gave place to the new, decentralized, multi-sensorial, linguistic network of twentieth century's postwar open societies, all these emancipating values and categories consequently found a common ground to exponentially emerge and take over our contemporary worldview. And of course this is now a reality we experience in our daily lives, at least as far as Organizations are concerned, for Western societies are rooted in corporations, companies, associations, foundations, among other forms of organized civil structures (Drucker, 2001; Castells, 2001) [7], [8].

Nevertheless, it may actually be quite surprising how Individuals also earned such an increasing prominence from postwar times up until now. For although individualistic values have been promoted all across modern history protestantism, capitalism, romanticism, among other currents, all found a way to enhance individualism - from the 1950s on, philosophers, writers and artists took a step further, as they started focusing on one's authentic condition That is, on the individual as a singular unity, whose existence even precedes his own human essence; which ultimately means that he can not be categorized, determined, catalogued by any kind of theoretical, cultural, social or other universal configuration, but only by himself, his freedom and his situation (Sartre, 1963, p.35) [9].

For the first time in history, the individual did not have to be a hero, or an anti-hero, or a remarkable character in a major plot, to earn the attention of the word. His own story, as an ordinary man, his reflections, feelings, anguishes and hopes (usually false ones) were more than enough to make him the protagonist of any great novel. Far more radical than their predecessors, postwar existentialists do not even need to consider unfulfilled existence as that of someone sickened to death - despairing over himself, in despair to want to be rid of himself (Kierkegaard, 2008, p.18) [10]. Why bother with such dramatic emotions? Just like the Camus's Stranger, Meursault, the new individual is more of an honest problem solver, he simply refuses to play the game (Bloom, 2008) [11] - of love, family, friendship, social/moral norms, or even life itself. But, of course, his honesty comes at a price. He is condemned to be disengaged, unempathic, detached from society, not because he lacks all sensibility, but precisely because of his passion for truth (ibid.). For he knows none of those social categories and generic human values can provide him with the absolute, existential, authentic one.

So, what is the authentic truth? Or what did existentialists such as Camus and Sartre mean by that? It was essentially a dilemma. On one hand, the individual can not be determined by categories, but only by his freedom and situation. On the other, he needs them, because without some sort of categorization there can also be no situation. After all, absolute universality and absolute singularity are both empty.

The first generation which tried to solve the authenticity dilemma became known as the beat generation. Poets such as Allan Ginsberg, Jack Kerouac, William Burroughs vigorously rejected social norms, economic materialism, bureaucratic establishment and institutionalized religion/morals. For the individual could never be determined by those external, obsolete, hypocritical, false abstract values. In this sense, authenticity was defined as a negative. Brought up during the collective bad circumstances of depression and war, the youth of the 1950s would distrust society as a whole:

"The origins of the word 'beat' are obscure (...) More than mere weariness, it implies the feeling of having been used, of being raw. It involves a sort of nakedness of mind, and, ultimately, of soul; a feeling of being reduced to the bedrock of consciousness. In short, it means being undramatically pushed up against the wall of oneself." (This is the Beat Generation, J. C. Holmes, 1952; Asher, 1994) [12]

The figure of James Dean became the american symbol of existentialist disengagement. But it was his desire to live intensely - his alleged openness to bisexuallity, his fabulated love-story with Pier Angeli, his passion for auto racing and his tragic death - what ultimately made him a hipster hero (Mailer, 2007) [13]. In search for what is hip, the young generations of the 50s would also crave for new experiences, for to be a true existentialist "one must be able to feel oneself - one must know one's desires, one's rages, one's anguishes, one must be aware of the character of one's frustration and know what would satisfy it." (Ibid.).

Therefore, the positive solution for the authenticity dilemma was defining the individual self, not in terms of general or social categories, but by means of the heuristic, syncretic, experimental categorization process we call lifestyle. And naturally, alternative cultures/subcultures could provide just that with a very rewarding sense of uniqueness and existential fulfillment; as Norman Mailer would put it in is famous article, The White Negro (1957):

"So there was a new breed of adventurers, urban adventurers who drifted out at night looking for action with a black man's code to fit their facts. The hipster had absorbed the existentialist synapses of the Negro, and for practical purposes could be considered a white Negro." (Ibid.)

The Ideology of Me was finally established among the most developed western countries. By embracing an alternative lifestyle, the individual was able to satisfy the void he emerged in due to social/moral disengagement, and fulfill his self with authentic feelings, passions, intellectual 
and spiritual ventures. Nevertheless, as we have already seen, this new ideology also contemplated or even privileged other forms of subjectivity - corporations, foundations, associations - i.e. organized versions of the equivalent individualistic/capitalistic self prominence $(\mathrm{Me})$; for all these agents/selves were interconnected in the same linguistic, communicational, economic and social-cultural network. And as far as these organizations were concerned, lifestyle was just the other side of the coin for one of the most demonized - yet systematically intrinsic contemporary phenomenon: consumerism.

\section{HiPPIES, YUPPIES AND THE GRUNGE GENERATION}

Providing us with a global glance on the popular vocable which portrayed the 1950s, Dan Fletcher also makes a simple and effective remark of what happened next: "As the first hipster generation aged, it was replaced by the etymologically diminutive hippies, who appropriated their fears about the Cold War but embraced the community over the individual." (2009) [14]. The Hippie Movement eventually turned all the alternative ethical/authentic values of its precedent decade mainstream, globalizing sexual revolution, recreational drug use, the desire for new experiences and altered states of consciousness; also promoting a vibrant curiosity for native, primitive and eastern spiritualities. Hence, it evolved into one of the most emblematic postmodern countercultures, with its own patterns and behaviors - far more politically active, artistically diversified (music, arts, performance) and communitarian.

Nonetheless, the hippie movement ended up having the most ironical effect, as it additionally contributed to reestablishing and reenforcing the basic equalitarian principles of the network paradigm which allowed contemporary individualism to have emerged in the first place. For as was pointed out before, the individual category actually depends on equality and it does not come alone, it implies an organizational rooted system. In other words, we should once again consider Individuals and Organizations not as a simple opposition, but as contrasting and complementary new forms of subjectivity which took place in our societies since the idealistic Subject was replaced. And it was precisely this interaction between these two categories which kept changing and regenerating the postmodern world.

Since the late $60 \mathrm{~s}$, individuals started participating more actively in the global productive system. Apart from freely embracing their lifestyle, their professional status and pragmatics was already quite different from that of the old industrial worker. Through formal education and technical experience, individuals were becoming more specialized and sophisticated in their working skills, contributing to the success of organizations with their rational abilities rather than their hands. Western countries were progressively engaging in the process that would ultimately result in the 1980-2000s Knowledge Society, an organizational rooted model which enhanced individual working autonomy as no other before:

"Most people in history were dependents. But they did not work for an organization. They were working for an owner, as slaves, as serfs, as hired hands on the farm; as journeymen and apprentices in the craftsman's shop; as shop assistants and salespeople for a merchant; as domestic servants, free or unfree; and so on. They worked for a 'master'. When blue-collar workers in manufacturing first arose, they still worked for a 'master'. [...] Only in this century has the 'master' been replaced by a 'boss', who, himself, ninety-nine times out of a hundred, is an employee and has a boss himself." (Drucker, 2001, p.45)

Benefiting from both hipster and hippie revolutions which liberated him from traditional norms as well as any other moral, social or even self oppression - and collaborating as an intelligent, highly qualified, well paid employee, the 1980s Yuppie openly celebrated capitalism. The system seemed to be working just fine, so there was no need for hypocrisy. It became explicit. After all, collective equality and greedy individualism were both founded on the same linguistic/communicational network and its intrinsic values. The electronic age was reaching its highest point, hence, Milton Freedman himself frontally expressed these values on his famous TV show Free To Chose, explaining what the Declaration of Independence and eminent personalities such as Thomas Jefferson really meant when stating all men are equal - i.e. they all must be treated as individuals who have each, separately, a right to life, liberty and the pursuit of happiness (Free to Chose Network, 2016) [15].

The Ideology of Me came out to the streets and avenues of the most cosmopolite cities - New York, London, Paris, Madrid - where not only the yuppies were feeling confident but every other ordinary citizen could proudly express themselves wearing bright colors, fancy hairstyles, ripped jeans, Dr. Martens, Converse All Star, bandanas, just like their favorite rock/pop stars - Prince, Boy George, Bruce Springsteen Madonna. And as for TV and Movie role models, they were also ostensively honest - Michael Keaton (Family Ties, 1982-1989) or even the infamous Gordon Gekko (Wall Street, 1987) acted as they would have nothing to hide. The authenticity dilemma seemed to have vanished. To be authentic meant to openly fulfill ones identity with glamorous consumerism, and its inherent correlations prestige, fame, wealth, romantic affairs. And naturally, the fall of the Berlin Wall in 1989 was the symbolic coronation of this long time awaited Kingdom of The Individual (Lipovetsky, 1986) [16], among the neoclassical remains of the idealistic Subject metanarratives (Lyotard, 2009) [17].

Nonetheless, could this Kingdom be for real if the actual individual was not? More than an explicit interrogation, this was the underlying feeling of the 90s. And it was an uncomfortable one. Existential emptiness could no longer be satisfied by vain glamour anymore. The decade started abruptly - the first Gulf War symbolized the legitimacy of armed conflicts based on capitalistic values, as the Yugoslavian Civil War exposed the fragilities of excommunist countries, founded on a unrealistic pipe dream. It was time to confront real live as it was - real politicians did not need to franticly believe in free market (as Margaret Thatcher and Ronald Reagan), they simply knew it was the best system and just had to improve it, make it more beneficial for their voters (Tony Blair, Bill Clinton - 'its the economy, stupid'); real businessman did not have to be 
infamously charming fictional characters (Gordon Gekko), but practical, informal, and casual (Bill Gates). For real life was made of normal people and their daily consumerism, events, setbacks, misunderstandings, joys and achievements.

Therefore, fictional stories should also be about nothing (David, 1992) [18], as the masterpiece TV Show Seinfeld illustrated so well - why bother with complex fantasy plots, when a dialogue/situational driven episode about a group of characters waiting for a table in a Chinese restaurant would do just fine? Or even better. People were fascinated by real live dramas, and that was also what made them laugh. The glamorous authenticity of the 80s was not honest, it was naif Actual people, authentic people did not live in amazing Manhattan penthouses, or on an Endeavour sailboat - with a pet alligator (Sonny Crockett, Miami Vice, 1984-1990) - but in a flat, with a sofa, a TV and a fridge as the domestic ex libris. Authenticity was of course, and once again, achieved by means of consumerism. But this time French wine, champagne and caviar were restricted to special occasions. For real life individuals consume Junior Mints, Drake's Coffee Cake, Pez, y Snickers (Bukszpan, 2015) [19].

The twentieth century ended in a very pragmatical economic and politic environment, along with an explicit and unapologetic promotion of ordinary individual desires and his right to unawareness - he just had to be himself living his daily pleasures, achievements, personal dramas. He did not have to care "about disasters, fires, floods, and killer bees (...) about the NASA shuttle falling in the sea" (Faith no More, 1998). And this was particularly expressed by the crude, raw, painfully realistic songs of the Grunge generation (Nirvana, Pearl Jam, Alice in Chains). One has to be authentic, and to be authentic is to be real, to feel the passion of individual reality. So in case one eventually happens to be absorbed by the fake, illusional, corrupt system - maybe as a consequence of a very pragmatical, cynical, organizational conspiracy (the FBI X-Files, the MTV music industry) - one might as well just kill himself. After all, individual life would not be real anymore, or in Kurt Cobain's words, it would not be fun anymore (Highland, 2016) [21].

\section{The AgE OF YOU: HIPSTER AND POST-HIPSTER TIMES}

The Digital Age has exponentiated individualistic autonomy in the most radical way. It has transformed the individual worker/consumer into a content producer, and of course this transformation also reconfigured the Ideology of Me, changing it into a whole new story:

"It's a story about community and collaboration on a scale never seen before. It's about the cosmic compendium of knowledge Wikipedia and the million-channel people's network YouTube and the online metropolis MySpace. It's about the many wresting power from the few and helping one another for nothing and how that will not only change the world, but also change the way the world changes." (Grossman, 2006) [22].

We are living in the Age of You. Evidently, this does not mean that society is no longer rooted in organizations - it still is, maybe even more, and perhaps in the most crude,

\footnotetext{
${ }^{1}$ From the song We Care a Lot (1985). It prophetically illustrates the spirit of the 90 s, both thematically and stylistically, becoming an emblem of Faith no More's album Who Cares a Lot (1998) [20]
}

oligarchical, monopolistic manner - but it is also an undeniable fact that, on a daily basis, each one of us is actively contributing to the global network society as never before. And we do it by our own initiative every time we make a comment, post a video or click the like button. Our creative autonomy is what makes the world go round.

The first cultural manifestation of this autonomy took the form of self awareness. Between 1999 and 2003, reality TV became a huge success (Big Brother, 2000; Survivor, 2000; American Idol, 2002). However, by filming and broadcasting ordinary individual lives, these shows only revealed to their vast audience one of the most well kept secret among audiovisual producers - there is no such thing as reality. The 1990s real individual was replaced by his vague quest for ironic authenticity - the white hipster was born. And if we take a look into his favorite things we just might be surprised how 'reality' could be so ironically over the top:

"(...) trucker hats; undershirts called "wifebeaters," worn alone; the aesthetic of basement rec-room pornography, flash-lit Polaroids, and fake-wood paneling; Pabst Blue Ribbon; "porno" or "pedophile" mustaches; aviator glasses; Americana T-shirts from church socials and pig roasts; tube socks; the late albums of Johnny Cash; tattoos." (Greif, 2010) [23].

Around the turn of the millennium, the great neo-hipster masterpiece the Big Lebowski (1998) was released. The Dude served as a role model not only for the white hipsters but also for all millennial generation. For what is beneath the 21 st century's hipster is not the quest for subcultural libido, as it was for the original ones, the 1950s beatniks; but an ironical sense of self awareness - there is no such thing as the real individual, so the new hipster demystifies reality precisely by overexposing it, usually through kitsch or 'over the top' aestheticization.

Moreover, approximately between the mid 2000s and the beginnings of the 2010s, the new hipster generation became increasingly sophisticated, in terms of lifestyle aestheticization. Benefitting from a virtually infinite source of information as well as proactive digital resources, individuals started realizing that not only was reality in fact a empty category, but also that they were the ones who were actually supposed to invent it. To be authentic became the ultimate manifestation of individualistic autonomy. The main goal was not to be naively real/authentic but to create authenticity as a form of originality, which provided the individual with the most noble, distinguished, exquisite or even spiritual virtue a human being can have: uniqueness.

In his 2010 New York Magazine article, Mark Greif identifies the Hipster Primitive as someone fascinated by nature, native/ecological cultures and country life - a regenerating worldview which could be especially expressed by music:

"Here are the names of some significant bands, post-2004: Grizzly Bear, Neon Indian, Deerhunter, Fleet Foxes, Department of Eagles, Wolf Parade, Band of Horses, and, most centrally, Animal Collective. (On the electronicprimitive side, LCD Soundsystem.) Listeners heard animal sounds and lovely Beach Boys-style harmonies; lyrics and videos pointed to rural redoubts, on wild beaches and in forests; life transpired in some more loving, spacious, and manageable future, possibly of a Day-Glo or hallucinatory 
brightness. It was not unheard of to find band members wearing masks or plush animal suits." (Ibid.)

Nevertheless, the 2000s-2010s hipster phenomenon can not be restricted to primitive or ecological values. It also has a substantial urban character, and neighborhood gentrification has been the perfect example of it - local bars, shops, markets have been recovered and esthetically renewed all over the world. For the key concept is precisely this: gentrification. But what do we really mean by gentrification?

It is a vague term, and as far as its underlying meaning is concerned, we should also not interpret it as an exclusively urbanistic trend. In this case, vagueness is not a bad thing. On the contrary, it is exactly what makes gentrification the most accurate vocable to describe how we face authenticity today. For that is what 21 st century's hipsters have been doing all along. Benefitting from an unprecedented individualistic autonomy, they do not content with regenerating city spaces, they actually spend their lives regenerating themselves. In other words, creating authenticity by gentrifying their own individuality in the most original, ironical way; i.e. recovering what could be more hip from past trends, to adapt, reinvent, or in a word, gentrify one's personality. So in this sense, perhaps what all new hipsters have in common is their own individualistic esthetical secrets. The problem is, can there be any secrets in the Digital Age, without being discovered, on a daily basis, by millions of people?

Evidently not. And that is why it probably no longer makes sense to talk about hipsters anymore. Creating authenticity has become a generalized phenomenon. Each one of us is free to do it at one's own will. There are no secrets, so no individual can state his uniqueness as opposed to the other's. Each one of us creates his own singularity without possibly competing against one another. For who can proclaim himself as a connoisseur only to find his secret published the very next day, by any other person, from any other country, on Facebook, Tweeter or Instagram?

Probably embracing the greatest fantasy of all, we are actually convinced that each one of us is incomparably special. So we project ourselves in the nebulous idea of what we imagine the ordinary individual of today might be. Of course we are aware of our creative authenticity, but we still believe in it, and probably more than ever. In a word, we have become hiperauthentic. We spend our lives estheticizing our daily lifestyles, gentrifying the ordinary individual as a whole, sharing it on the web, eventually identifying ourselves with our spectrum. But who/what is this spectrum?

Viral videos illustrate it with peculiar stereotypes and actions, usually representing the ordinary individual as someone happy who loves dancing, singing, lip-syncing or performing any other superficial pop diversion while managing daily routine (Waxman, 2014; McIntyre, 2015) [24], [25] - he/she is the mother, Tianne King who makes choreographies with her daughter Heaven; the unfortunate passenger who misses the last flight and spends the night alone in the airport, making a videoclip of Celine Dion's All By Myself; the Cop from Denver doing lip sync in his car. And of course everyone wants to be like him/her, even celebrities and politicians. Instead of promoting themselves in a mythical scenario - a stage among the gods - Jennifer Lopez, Adele and Justin Bieber prefer to join James Corden in a Carpool Karaoke on his way to work. Jimmy Fallon, Emma Stone, Will Ferrel, Kevin Hart have so much fun making lip sync battles; and even the President of The United States would not refrain from singing and dancing in official acts, as well as explaining his healthcare system with fancy jokes. After all, we are all ordinary individuals. Although perhaps some are more then others.

\section{CONCLUSIONS}

In order to understand how, and why, we create our own authenticity today, we have to approach the actual dilemma and its causes. And to comprehend its causes we have to search for its context. Hence, we started to expose how the old idealistic Subject's model gave place to the Network Paradigm, which allowed a whole new world to emerge, with its own new forms of subjectivity: Organizations and Individuals.

These two forms of subjectivity both express the concept of $\mathrm{Me}$ and its correspondent ideology. But naturally, the individual presupposes subjectivity at its most radical form, the absolute singularity of existence. And it was precisely this existential category which has been earning a surprising prominence since the postwar up until now.

The first generation to focus on the individual as the main premise of all philosophical questions, or any other social, moral, literary, artistic concern, was the beat generation. Highly influenced by Sartre's existentialism, the beatniks immediately detected the authenticity dilemma. For if all social morals and religious dogmas could not define the individual - but only his freedom and his situation - where else was he suppose to find his own identity? Personalities such as Allan Ginsberg, Jack Kerouac, William Burroughs rejected traditional values, embracing subcultures as a form of authenticity categorization. In the following decade, hippies also promoted hipster's values - experimentation, sexual liberation, drug experiences and oriental/native/primitive religions as an alternative to christianity - although privileging the community equality over the individual.

Nevertheless, since the old idealistic Subject was replaced with the new communicational/linguistic Network Paradigm, equality values became part of the system, even though it was promoted as a counterculture. For only equality could bring together all different agents, organizations and individuals within the same relativistic panorama of open/free societies. And it was precisely this interaction between individuals and organizations which caused two basic contemporary phenomena:

1) Authenticity categorization through lifestyle. In other words, creating authenticity by means of consumeristic identification.

2) Individual's specialization in order adapt, as workers, to the social organizational productive system.

Individuals became increasingly sophisticated and autonomous, participating more actively in the global productive process. As intelligent workers, individuals felt particularly confident to openly express themselves as glamorous consumers and successful yuppies, in the 80s. To be authentic was to frontally express the desires of the self: fame, fortune and love.

But were they for real? This was the underlying interrogation of the 90s. Real individuals were not rich and 
famous, they were normal people, of course. Living in a very pragmatical and cynical socio-political context, individuals started privileging their own realistic lives small events, conflicts, dramas, achievements - over glamorous pipe dreams. Hence, to be authentic was to consume real daily products and simply rejoice with them. As for the young generations, they felt compelled to feel their own individual reality in the most crude manner, as grunge music illustrated.

Finally, the 21st century was the consummation of the Digital Age. The internet became increasingly efficient, agile, easy to use, and an amazing interactive and proactive tool. It just took over our lives. Digital resources transformed the individual's social condition, from a simple worker/consumer to a content producer. The Ideology of Me was radically reconfigured in the Age of You, providing individuals with an unprecedented autonomy.

The first cultural manifestation of this autonomy was self awareness. Of course we have been creating our own authenticity since the 1950 s, but the new 21 st century hipsters were actually able to realized it as no other social movement before. From reality TV mania, they easily learned that there is no such thing as reality, especially as far as audiovisual media is concerned. So they became ironic, recreating it and even surpassing it by exposing the "real individual" as an old fashion, over the top "realistic" stereotype.

The second new hipster generation was also ironical, but far more esthetically concerned. What started with a primitive and ecological revivalism, eventually expanded to the city and was publicly expressed as urban gentrification the recovering of local shops, markets, old bars became almost an obsession all over the western world. But what does gentrification exactly mean? It is a vague concept, but it is precisely its vagueness what allows us to better understand the hipster movement as a whole. For it was not only urbanistic recovering what was at stake between this 2000s-2010s esthetical revival frenzy. The actual individual was constantly being recovered, revisited, recreated - in a word: gentrified - in his own way, readopting old pop trends and styles. So to be authentic was to create one's own gentrification with original, exquisite, vintage products, habits and customs. And creative success and quality was determined by a kind of connoisseurs secrecy. But is it possible to actually own any kind of secret in the Digital Age?

Of course not. Whatever fashionable trend or product one finds in a obscure traditional street, or maybe even in a lost village, will probably be available on eBay next morning. And that is why hipster generation inevitably ended. Nevertheless, it gave place to a new kind of gentrification. Today we project the individual as a whole. We glamorously promote his lifestyle as a continuous celebration and aestheticization. Almost all top viral videos confirm it, for us the ordinary individual of today is the absolute role model - he is happy, glamorous, lighthearted, and always rejoicing, singing, dancing and lip syncing on his way to work. No wonder everyone - including celebrities and politicians - wants to be like him.

After all, we may all instinctively know that we are living the Ideology of Me in the Age of You, and that we also have been creating authenticity at least since the first hipster generation (1950s). But of course, that does not necessarily mean that Me and You cannot be something for real.

\section{REFERENCES}

[1] K. Immanuel, Crítica da Razão Pura, Lisboa: Fundação Caloust Gulbenkian, 2001.

[2] M. Marshall, The Gutenberg Galaxy, Toronto: University of Toronto Press, 2002.

[3] I. Harold, The Bias of Communication, Toronto: University of Toronto Press, 1995.

[4] Heidegger, Being and Time, Cornwall: Blackwell Publishers, 2001.

[5] W. Ludwig, Tractatus Logico-Philosophicus, Trench, Trubner \& Co., Ltd, 1992.

[6] W. Ludwig, Philosophical Investigations / Philosophische Untersuchungen, London: The Macmillan Company, 1953.

[7] D. Peter, The Essential Drucker, New York: HarperCollings Publishers, 2001.

[8] C. Manuel, La Galaxia Internet, Madrid: Plaza \& Janés, 2001.

[9] S. Jean-Paul, Reflexões sobre a Questão Judaica, São Paulo: Europeia do Livro, 1963.

[10] K. Soren, The Sickness unto Death, London: Pinguin Books, 2008.

[11] B. Harold, Albert Camus's the Stranger, New York: Infobase Publishing, 2008.

[12] A. Levi. (July 24th, 1994), This is the Beat Generation. [Online]. Available: http://www.litkicks.com/ThisIsTheBeatGeneration

[13] M. Norman. (2007). The white Negro (Fall 1957). [Online]. Available: https://www.dissentmagazine.org/online_articles/the-white-negrofall-1957

[14] F. Daniel. (July 29th, 2009). Hipsters. [Online]. Available: http://content.time.com/time/arts/article/0,8599,1913220,00.html

[15] Free to choose network. (2016). [Online]. Available: http://www.freetochoose.tv/ftc80.php

[16] L. Gilles, La Era del Vacío: Ensayos Sobre el Individualismo contemporÁneo, Barcelona: Editorial Anagrama, 1986.

[17] L. Jean-François. La Condición Postmoderna, Madrid: Cátedra, 2009.

[18] D. Larry. (1992). Episode 43 - The Pitch [TV Script]. [Online]. Available: http://www.seinology.com/scripts/script-43.shtml

[19] B. Daniel. (2015). Seinfeld' is good for business (yada yada yada) [Online]. Available: http://fortune.com/2015/06/27/seinfeld-products/

[20] Faith no More, Who Cares a Lot? The Greatest Hits, UK \& Europe: Slash London Records, 1998.

[21] H. Josh. (2016). Kurt Cobain's Suicide Note. [Online]. Available: http://kurtcobainssuicidenote.com/kurt_cobains_suicide_note.html

[22] G. Lev. (2006). You-Yes, You-Are TIME's person of the year [Online]. Available: http://content.time.com/time/magazine/article/0,9171,1570810,00.htm 1

[23] G. Mark. (2010). What Was The Hipster? [Online]. Available: http://nymag.com/news/features/69129/

[24] W. B. Olivia. (2014). Top 10 viral videos. [Online]. Available: http://time.com/3588022/viral-videos/

[25] M., Hugh. (2015). YouTube's most viral videos of 2015 are all about music. [Online]. Available: http://www.forbes.com/sites/hughmcintyre/2015/12/16/youtubesmost-viral-videos-of-2015-are-all-about-music/\#2683264e781f

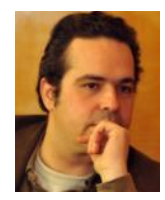

Rodrigo Almeida Sousa was born in Johannesburg in 1975. $\mathrm{He}$ is a Portuguese/south-African writer and academic researcher at CIC.DIGITAL (University of Porto). Considering his wide interdisciplinary background Philosophy (BA/Catholic University of Portugal), Literary Theory (MA/University of Lisbon), Advanced Studies in Applied Creativity (Autonomous University of Madrid) and Audiovisual Communication (PhD/Complutense University of Madrid) - he usually conciliates different conceptual and/or cultural dynamics, historical events, developments or myths, with media supports and paradigms, in order to approach philosophical questions on social studies, particularly those concerning Creativity and Communication. Lately he has been focusing on contemporary individualism, digital culture, viral videos and implicit misconceptions about creative inspiration and talent. And of course these issues personally matter to him, since he is also the author of successful Portuguese children's books (My School would Make a Movie, 2011; Louie the Cootie, 2013) as well as screenplays of short and full length award winning movies (The Grave, Luis Alves, 2011; Sign, António B. Correia, 2011). 